\title{
Kajian Pengawasan Pemanfaatan Sumberdaya Air Tanah di Kawasan Industri Kota Semarang
}

\author{
Deo Volentino ${ }^{1}$ \\ PT Bank UOB Indonesia \\ DKI Jakarta, Indonesia
}

\begin{abstract}
Abstrak: Kawasan industri didalam berbagai aktivitasnya, membutuhkan air bersih dalam jumlah yang relatif cukup besar. Berhubung penyediaan air bersih dari PDAM tidak memadai, maka preferensi kawasan industri bergeser ke alternatif lain yaitu sumber air tanah. Pemanfaatan maupun pengawasan upaya konservasi dan pendayagunaan air tanah, belum terselenggara dengan sebagaimana mestinya. Melihat permasalahan tersebut maka diangkat research question yaitu bagaimana pengawasan pemanfaatan dan upaya konservasi air tanah di Kawasan Industri Kota Semarang? Tujuan penelitian ini adalah untuk mengkaji pengawasan pemanfaatan air tanah oleh pemerintah di kawasan industri Kota Semarang. Guna mencapai tujuan ini maka pendekatan penelitian ini menggunakan model deskriptif kuantitatif, dengan responden yaitu pengelola kawasan industri, Dinas ESDM Propinsi Jawa Tengah, Dinas PSDA Kota Semarang, BLH Kota Semarang, dan DPKD Kota Semarang. Analisisnya meliputi analisis karakteristik industri yang memanfaatkan air tanah dilihat dari jenis dan jumlah industri, volume kebutuhan, jumlah sumur dan kedalamannya, ketersediaan jaringan PDAM, dan lokasi industri. Analisis berikutnya yaitu analisis pengawasan pemanfaatan sumber daya air tanah oleh BLH Kota Semarang, ESDM propinsi Jawa Tengah, PSDA Kota Semarang, dan DPKD Kota Semarang. Berdasarkan hasil analisis penelitian ini diketahui bahwa seluruh kawasan industri memiliki kecenderungan untuk memanfaatkan air tanah dibandingkan air PDAM. Namun, banyak pengelola kawasan tidak dapat menunjukkan surat izin sumur artesis yang dioperasikan dan belum melakukan upaya konservasi. Penelitian juga menunjukkan PSDA Kota, ESDM Propinsi, dan BLH Kota belum melakukan pengawasan rutin ke unit-unit industri terkait aktivitas pemanfaatan air tanah, sehingga tingkat pengawasannya dianggap lemah. Apabila temuan penelitian ini tidak segera diperbaiki dengan sungguh-sungguh, maka potensi ancaman krisis air dapat terjadi di Kota Semarang. Dalam rangka mengantisipasi potensi dampak pemanfaatan air tanah yang tidak berlangsung dengan sebagaimana mestinya, maka penelitian ini menawarkan rekomendasi yaitu : pengelola kawasan industri perlu meningkatkan disiplin pencatatan dan pelaporan berbagai karakteristik pemanfaatan dan upaya konservasi pendayagunaan air tanah sesuai peraturan perundangan yang sudah ada; instansi terkait perlu meningkatkan mutu pengawasan pemanfaatan air tanah; peneliti/penggiat pelestarian air tanah perlu melakukan penelitian yang lebih komprehensif guna menemukan kondisi riil air tanah pada saat ini di kawasan industri Kota Semarang.
\end{abstract}

Kata kunci: pengawasan, air tanah, kawasan industri

Abstract: Industrial estates in various activities, need clean water in relatively large amounts. Since the provision of clean water from PDAM is inadequate, hence the preference shifted to the industrial alternative source of water the soil. Utilization and monitoring conservation and

\footnotetext{
${ }^{1}$ Korenspondensi Penulis: PT Bank UOB Indonesia, DKI Jakarta

Email: volentinodio@gmail.com
} 
utilization of ground water, has not held with as it should. Seeing this problem, the research question raised is how to control the utilization and conservation of ground water in Semarang City Industrial Zone? The purpose of this study was to assess the utilization of ground water monitoring by the government in the industrial city of Semarang. To achieve this goal the approach of this study using quantitative descriptive models, the respondents are managers of industrial areas, Central Java Province Department of Energy and Mineral Resources, PSDA Semarang, Semarang City BLH and DPKD Semarang. The analysis includes the analysis of the characteristics of the industries that use ground water, judging from the type and number of industries, water volume requirements, number of wells and the depth, availability of PDAM network, and industrial sites. Subsequent analyzes were analyzed for monitoring ground water resource utilization by BLH Semarang, Central Java province EMR, PSDA Semarang, Semarang City and DPKD. Based on the analysis of this research, note that the entire industrial area has a tendency to use ground water than PDAM water. However, many managers were not able to show the license artesian wells operated and have not made conservation efforts. Research also showed PSDA City, EMR Provincial and City BLH have not do routine monitoring to industrial units that use ground water related activities, so the level of supervision is considered weak. If the findings of this study are not immediately fixed in earnest, the potential threat of a water crisis can occur in the city of Semarang. In order to anticipate the potential impact of the utilization of ground water that does not take place as it should, this study offers recommendations: industrial area managers need to improve the discipline of recording and reporting of the various characteristics of the utilization and conservation of ground water utilization in compliance with existing legislation; agencies need improve the quality of ground water utilization monitoring; researcher / activist conservation of ground water need to do a more comprehensive study to find the real condition of the ground water at this point in the industrial city of Semarang.

Keywords: monitoring, groundwater, industrial

\section{Pendahuluan}

Air adalah kebutuhan pokok mahluk hidup termasuk didalamnya manusia. Dalam melanjutkan kelangsungan kehidupan rumah tangga sehari-hari maupun kebutuhan proses industri sangat memerlukan ketersediaan air bersih yang memadai. Pada umumnya suatu daerah yang subur ditandai dengan debit air tanahnya yang tinggi, sebaliknya daerah yang kurang subur bahkan gersang debit air tanahnya terbatas. Air menduduki urutan prioritas persyaratan penting dalam mendukung laju proses perkembangan suatu daerah. Jaminan kontinuitas ketersediaan air bersih yang memadai menjadi daya tarik yang sangat kuat bagi masyarakat untuk datang bermukim dan aktivitas industri di wilayah tersebut. Laju pertumbuhan jumlah penduduk disertai akselerasi aktivitas industri di suatu wilayah, selalu berbanding lurus dengan peningkatan kebutuhan akan air bersih.

Berbicara tentang penyediaan kecukupan air bersih, pemerintah sudah memberikan otoritas dan tanggung jawab kepada institusi PDAM, akan tetapi pada realitasnya belum mampu memenuhinya secara memadai hingga pada saat ini. Keadaan tersebut memotivasi masyarakat untuk mengambil air tanah dalam memenuhi kebutuhan air bersih mereka sehari-hari, terutama memenuhi kebetuhan dunia industri dalam jumlah yang besar.

Menurut Peraturan Pemerintah No.43 Tahun 2008 disebutkan bahwa, penggunaan air tanah untuk berbagai keperluan (termasuk didalamnya bagi sektor industri), merupakan pilihan kedua, apabila air permukaan sudah tidak mencukupi, dengan syarat tetap memperhatikan upaya konservasi mencakup pencegahan kerusakan lingkungan. Pemenuhan kebutuhan air bersih di beberapa kawasan industri Kota Semarang sesungguhnya dapat dipenuhi dengan menggunakan air permukaan saja. Tetapi pada kenyataannya, disinyalir seluruh sektor industri lebih memilih sumberdaya air tanah untuk 
memenuhi kebutuhan air bersih mereka di Kota Semarang. Pembangunan wilayah perkotaaan tanpa perencanaan matang mengakibatkan terjadinya alih fungsi lahan dan perubahan topografi. Pengeprasan daerah perbukitan sebagai kawasan tandon air, menjadi material bangunan maupun penambangan memperparah kerusakan topografi permukaan tanah. Kurun waktu tahun 1987 sampai dengan 2004 terjadi penurunan fungsi lahan terbuka di Kota Semarang. Peningkatan lahan terbangun dari 33\% luas Semarang menjadi $43 \%$ dari total luas. Lahan persawahan menurun dari 17\% dari luas Semarang menjadi hanya $8 \%$.

Data Bappeda Kota Semarang (2010) menunjukkan bahwa kebutuhan air bersih perpipaan bersumber dari 7 bangunan produksi dengan kapasitas total sebesar $1.853 \mathrm{lt} / \mathrm{dt}$ atau 58.436.208 m3. Kebutuhan air di Kota Semarang pada tahun 1999 sebesar 48.407.307 m3, pada tahun 2005 total kebutuhan naik menjadi 68.568.239 m3. Proyeksi kebutuhan air di Kota Semarang menurut RTRW pada tahun 2030 mencapai 336 juta m3 lebih (termasuk asumsi tingkat kebocoran PDAM 25\%). Jika kita lihat pada data PDAM tentang pemakaian air, maka total pemakaian yang tercatat pada tahun 2008 adalah $34.277 .257 \mathrm{~m} 3$, dimana $87 \%$ digunakan untuk kebutuhan rumah tangga.

Menilik kebutuhan air bersih masyarakat pada tahun 2005 dengan pemakaian air dari PDAM menunjukkan bahwa setengah dari kebutuhan kota dipenuhi melalui sumber non perpipaan baik dari air sumur dangkal, air tanah, maupun mata air yang ada. Fakta tersebut didukung studi yang dilakukan JICA (dalam Prihantoro, 2011), bahwa eksploitasi air bawah tanah di Semarang sebesar 0,43 juta m3/tahun pada 1990 dan meningkat sebesar 35,64 juta m3/tahun pada tahun 1998. Menurut Dinas PSDA Semarang diperkirakan terdapat sekitar 1000 sumur ABT sampai saat ini baik yang berizin maupun tidak. Akibat pembangunan, perubahan lahan, dan perubahan iklim memberikan ancaman pengurangan air bersih pada masa yang akan datang. Sehingga diperlukan upaya konservasi terhadap sumber daya air.

Oleh karena itu dipandang perlu melakukan suatu kajian yang komprehensif terhadap upaya pemanfaatan air tanah oleh kawasan industri dan upaya pengawasan yang dilakukan pemerintah Kota Semarang dalam menanggapi aktivitas tersebut

\section{Kajian Literatur}

Terdapat lima sumber air yang dapat dimanfaatkan bagi kebutuhan kegiatan perkotaan (Nace, 1976), yaitu:

a. Air hujan, yaitu air hasil kondensasi uap air yang jatuh ke tanah,

b. Air tanah, yaitu air yang mengalir dari mata air, sumur artesis atau diambil melalui sumur buatan,

c. Air permukaan, yaitu air sungai dan danau,

d. Desalinasi air laut atau air payau/asin, dan

e. Hasil pengolahan air buangan.

Dari kelima sumber air tersebut, air tanah dan air permukaan merupakan pilihan sumber air yang utama untuk dimanfaatkan. Hal ini disebabkan kedua sumber tersebut mudah didapat, jumlahnya besar dan secara kualitas relatif lebih baik.

Menurut Kodoatie (2003) air tanah adalah sumber air yang terdapat di bawah permukaan tanah pada lajur/zona jenuh air (zone of saturation). Air tanah berasal dari air hujan dan air permukan yang meresap (infiltrate) mula-mula ke zona tak jenuh (zone of aeration), kemudian meresap semakin mendalam hingga mencapai zona jenuh air dan akhirnya menjadi air tanah. Air tanah adalah salah satu fase dalam daur hidrologi, yakni suatu peristiwa yang selalu berulang dari urutan tahap yang dilalui air dari atmosfer ke 
bumi dan kembali ke atmosfer. Penguapan dari darat, laut atau air pedalaman selanjutnya terjadi pengembunan membentuk awan, pencurahan, pelonggokan dalam tanah atau badan air kemudian penguapan kembali.

Menurut Wahyuni (dalam Rizki, 2003), potensi sumberdaya air tanah yang dapat dimanfaatkan secara langsung adalah:

a. Air tanah dangkal (akuifer tak tertekan), yakni air yang tersimpan dalam akuifer dekat permukaan hingga kedalaman (tergantung kesepakatan) 15 sampai $40 \mathrm{~m}$. Air tanah dangkal dimanfaatkan secara langsung untuk keperluan kegiatan non pertanian, khususnya untuk keperluan rumah

b. Air tanah menengah atau dalam (akuifer tertekan), yakni air yang tersimpan dalam akuifer pada kedalaman lebih dari $40 \mathrm{~m}$ (apabila kesepakatan air tanah dangkal hingga kedalaman $40 \mathrm{~m}$ ). Biasanya dimanfaatkan oleh PDAM atau industri milik.

Sebanyak 80 cekungan air tanah terdapat di P.Jawa dan P.Madura dengan potensi air tanah sekitar 41 milyar $\mathrm{m} 3 /$ tahun. Hamparan cekungan air tanah banyak yang lintas provinsi, kabupaten/kota dan ada juga yang lintas negara, serta sering juga dijumpai berada di bawah permukaan laut. Luas tiap cekungan air tanah tidak sama, tergantung kepada kondisi hidrogeologi setempat. Penentuan CAT bukan didasarkan pada batas administrasi melainkan pada batas hidrogeologis, oleh karena itu banyak CAT yang keberadaannya melintasi dua wilayah administrasi, bahkan bisa lebih. Di kota Semarang terdapat 2 CAT, yaitu CAT Ungaran dan CAT Semarang-Demak. Batas hidrogeologis kedua CAT ini tidak di Kota Semarang saja, tetapi turut meliputi Kab. Semarang dan Kab. Demak.

Pemanfaatan air tanah sebenarnya diatur oleh pemerintah seperti yang diamanatkan oleh UUD 1945 Pasal 33 ayat 1. Produk kebijakan selaku fungsi kontrol dalam pemanfaatan sumberdaya air memang masih menunjukkan kelemahan. Cukup sulit untuk membatasi pergerakan industri dalam menggunakan air tanah sebagai alternatif sumberdayanya. Aturan penggunaan sumberdaya air yang telah diatur dalam UU No. 7 tahun 2004 dan PP No. 42 Tahun 2008 dan PP No. 43 tahun 2008 ternyata menjadi muara permasalahannya. Beberapa pasal dalam peraturan tersebut memberikan peluang privatisasi sektor penyediaan air minum, dan penguasaan sumber-sumber air (air tanah, air permukaan, dan sebagian badan sungai) oleh badan usaha dan individu. Akibatnya, hak atas air bagi setiap individu terancam dengan adanya peluang privatisasi dan komersialisasi air di Indonesia.

Penggunaan sumberdaya air untuk kegiatan industri umumnya digunakan untuk proses produksi, pendinginan, pembuangan limah. Besarnya kebutuhan air industri antara lain ditentukan oleh kebutuhan satuan produksi/unit, kebutuhan air per tenaga kerja dan kebutuhan pertambahan nilai atau nilai produksi. Jumlah konsumsi air bersih per jenis industri berbeda - beda oleh karena adanya perbedaan dalam tahapan dan beban produksi. Kebutuhan air bersih paling besar terdapat pada jenis industri minuman, bahan makanan, makanan, bahan kimia industri ,dan bahan kimia lain. Sedangkan konsumsi air terkecil terdapat pada jenis industri kayu, semen dan kapur, dan perhiasan.

Hak guna pakai air dari pemanfaatan air tanah diperoleh dengan izin yang diberikan oleh pemerintah kabupaten. Izin pemakaian air tanah dapat diberikan kepada perseorangan, badan usaha, instansi pemerintah, atau badan sosial seperti yayasan, rumah ibadah, dan sekolah. Lampiran IV,V,VI Kepmen ESDM No: 1451K/10/MEM/2000 menyebutkan bahwa kegiatan eksplorasi, pengeboran termasuk penggalian, penurapan dan pengambilan air bawah tanah hanya dapat dilaksanakan setelah memperoleh izin dari Bupati/Walikota, selaku penyelenggara teknis tugas pemerintah di bidang pengelolaan air bawah tanah. Berhubung hingga saat ini belum ada dasar hukum berbentuk Perda sebagai turunan dari PP No : 43 Tahun 2008, Kepmen ESDM No 1451K/10/MEM/2000, dan peraturan perundangan lainnya tentang air tanah di wilayah administratif Kota Semarang, 
maka dasar hukum aparat yang berwenang terkait air tanah masih dari tingkat Propinsi Jawa Tengah dengan Perda Nomor 8 Tahun 2011.

Pemanfaatan air tanah memerlukan pengawasan guna menjaga kelestarian air dan lingkungannya. Berdasarkan Kepmen No : 1541K/10/MEM/2000, menyatakan bahwa kegiatan pengawasan dalam rangka kegiatan eksplorasi air bawah tanah, pengeboran dan/atau penurapan mata air, pengambilan air bawah tanah dan pencemaran serta kerusakan kelangsungan air bawah tanah dilakukan oleh Bupati/Walikota dan Masyarakat.

Dalam Peraturan Pemerintah No. 43 Tahun 2008 diatur mengenai pengendalian daya rusak air tanah yang ditujukan untuk mencegah, menanggulangi intrusi air asin, dan memulihkan kondisi air tanah akibat intrusi air asin, serta mencegah, menghentikan, atau mengurangi terjadinya amblesan tanah. Pengendalian daya rusak air tanah dilakukan dengan mengendalikan pengambilan air tanah dan meningkatkan jumlah imbuhan air tanah untuk menghambat/mengurangi laju penurunan muka air tanah. Pengawasan terhadap pengguna air tanah yang berizin dilakukan oleh Dinas PSDA Kota, bekerjasama dengan Dinas ESDM Jawa Tengah selaku penerbit rekomendasi teknis.

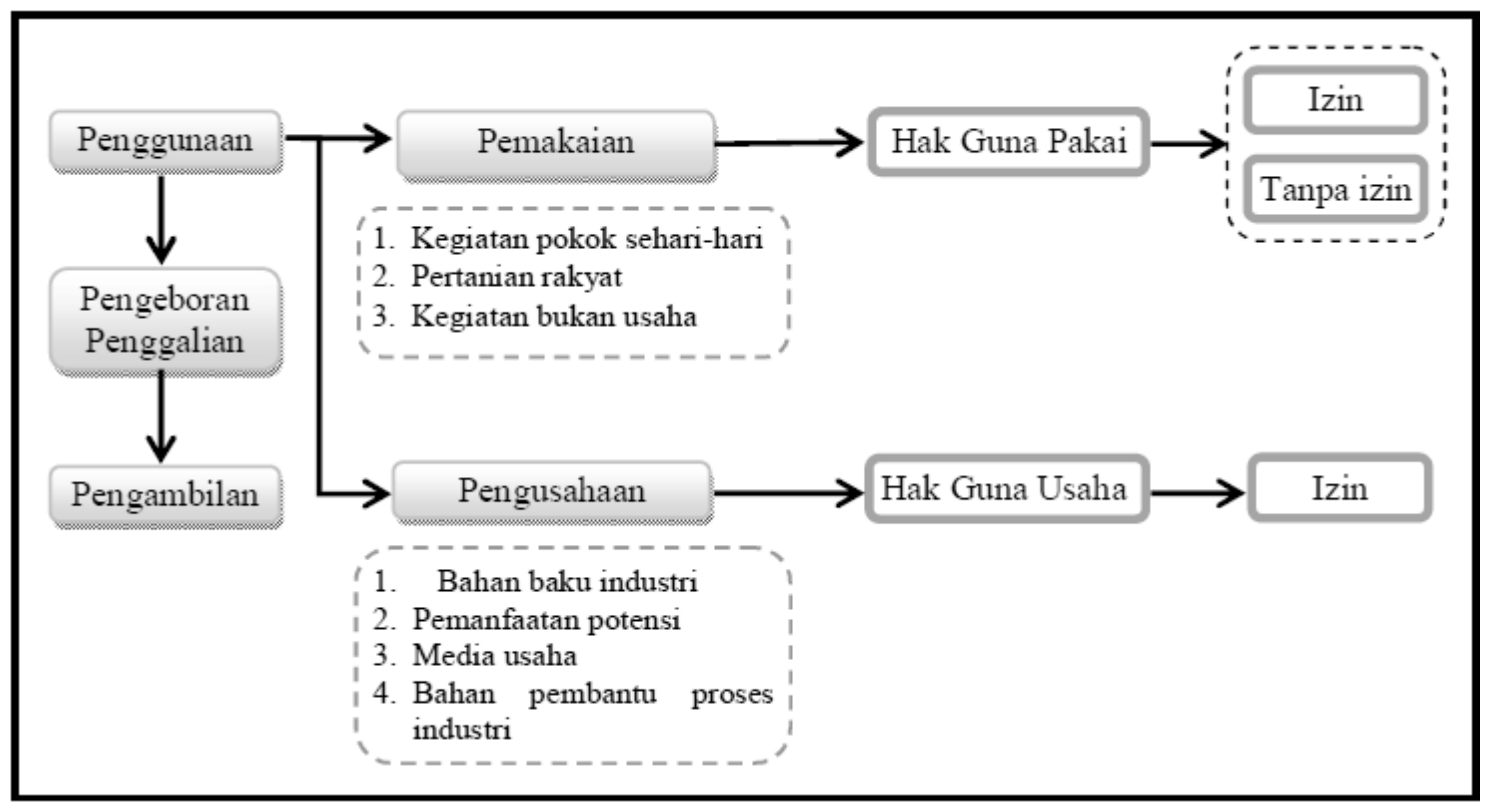

Sumber: Kodoatie dkk, 2002

\section{Gambar 1 Diagram Alir Penggunaan Air}

\section{Metodologi Penelitian}

Jenis penelitian yang digunakan adalah penelitian deskriptif. Singarimbun dan Effendy (1995 : 4) menyebutkan penelitian deskriptif sebagai penelitian yang dimaksudkan untuk melakukan pengukuran yang cermat mengenai suaatu fenomena tertentu dengan cara menafsirkan data yang telah ada. Pendekatan penelitian yang digunakan dalam studi ini adalah analisis deskriptif kuantitatif. Data yang diperoleh melalui instrumen : kuesioner, wawancara, observasi lapangan, data sekunder lainnya. Data yang terkumpul tersebut terlebih dahulu dikelompokkan menurut fenomena yang sejenis, kemudian disusun 
kedalam tabel sederhana, selanjutnya mendeskripsikan fenomena tertentu berdasarkan dari aspek-aspek penelitian yang telah ditentukan.

\section{Analisis}

Delapan Kawasan Industri Kota Semarang yang menjadi lokasi penelitian ini secara geografis terletak diatas Cekungan Air tanah Semarang - Demak sehingga potensi air tanah tersebut dapat dimanfaatkan dengan mudah. Lokasi yang menguntungkan ini menjadikan pengeboran air tanah sebagai sumber air bersih utama untuk menjalankan aktivitas industri. Sediaan air tanah berlimpah di wilayah CAT memberikan kemudahan kawasan industri untuk menyediakan air bersih kebutuhan aktifitas industrinya. Jumlah sumur artesis di 8 kawasan industri hanya ada 35 sumur bor yang terlaporkan dan dipergunakan oleh 139 jenis sektor industri dengan berbagai jenis produk. Penggunaan air tanah di industri pada umumnya adalah untuk industri yang bergerak di sektor makanan, minuman, tekstil, laundry, bahan kimia, pengolahan ikan, plastik, dan gudang buah. Jenis industri tersebut tergolong industri yang memerlukan sediaan air bersih cukup banyak. Hal ini berdampak terhadap pemanfaatan air tanah sebagai bahan baku utama atau bahan pembantu dalam proses produksi dengan kapasitas cukup besar.

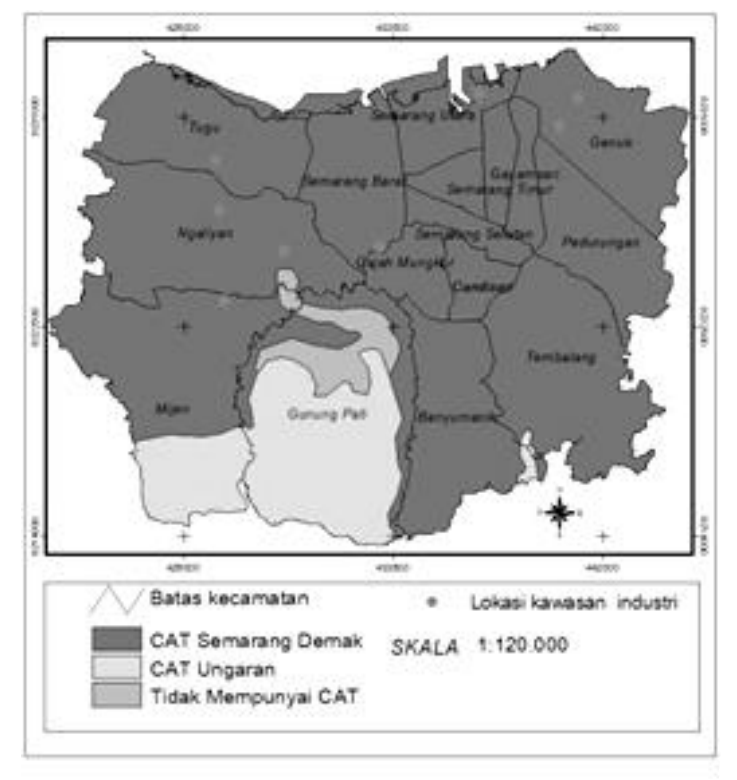

Sumber: Bappeda Kota Semarang, 2008.

\section{Gambar 2 CAT Semarang - Demak Dan Lokasi Kawasan Industri}

Sumber air bersih yang dipergunakan di 8 kawasan industri semata-mata hanyalah dari sumber air tanah (lihat Tabel 1). Dilihat dari preferensi pemanfaatan sumber air bersih, faktor yang mendorong kawasan industri tertarik memanfaatkan sumber air tanah antara lain karena sumber air PDAM tidak ada (12,5\%); Sebanyak $1(12,5 \%)$ kawasan industri menyatakan air PDAM tidak cukup; Sebanyak 2 (25\%) kawasan industri menyatakan karena air tanah lebih murah/mudah didapat; dan sebesar 4 (50\%) kawasan industri menyatakan karena kuantitas, kualitas dan kontinuitas debit air tanah lebih terjamin. Preferensi ini semakin dikuatkan oleh akses eksisting jaringan PDAM yang tampak pada 
gambar di bawah. Pada gambar tersebut, jaringan PDAM masih terkonsentrasi di Semarang wilayah tengah, selatan, dan timur.

Tabel 1. Keragaman Jenis Sumber Air Bersih

\begin{tabular}{l|l|c|c}
\hline No & $\begin{array}{c}\text { Jenis } \\
\text { Sumber Air }\end{array}$ & $\begin{array}{c}\text { Jlh } \\
\text { Kawasan }\end{array}$ & \% \\
\hline 1 & Air PDAM & 0 & 0.0 \\
\hline 2 & Air Sungai & 0 & 0.0 \\
\hline 3 & Air Danau Buatan & 0 & 0.0 \\
\hline 4 & Air Sumur Gali & 1 & 12.5 \\
\hline 5 & $\begin{array}{l}\text { Air Sumur Bor } \\
\text { Artetis }\end{array}$ & 7 & 87.5 \\
\hline & Total & 8 & 100.0 \\
\hline
\end{tabular}

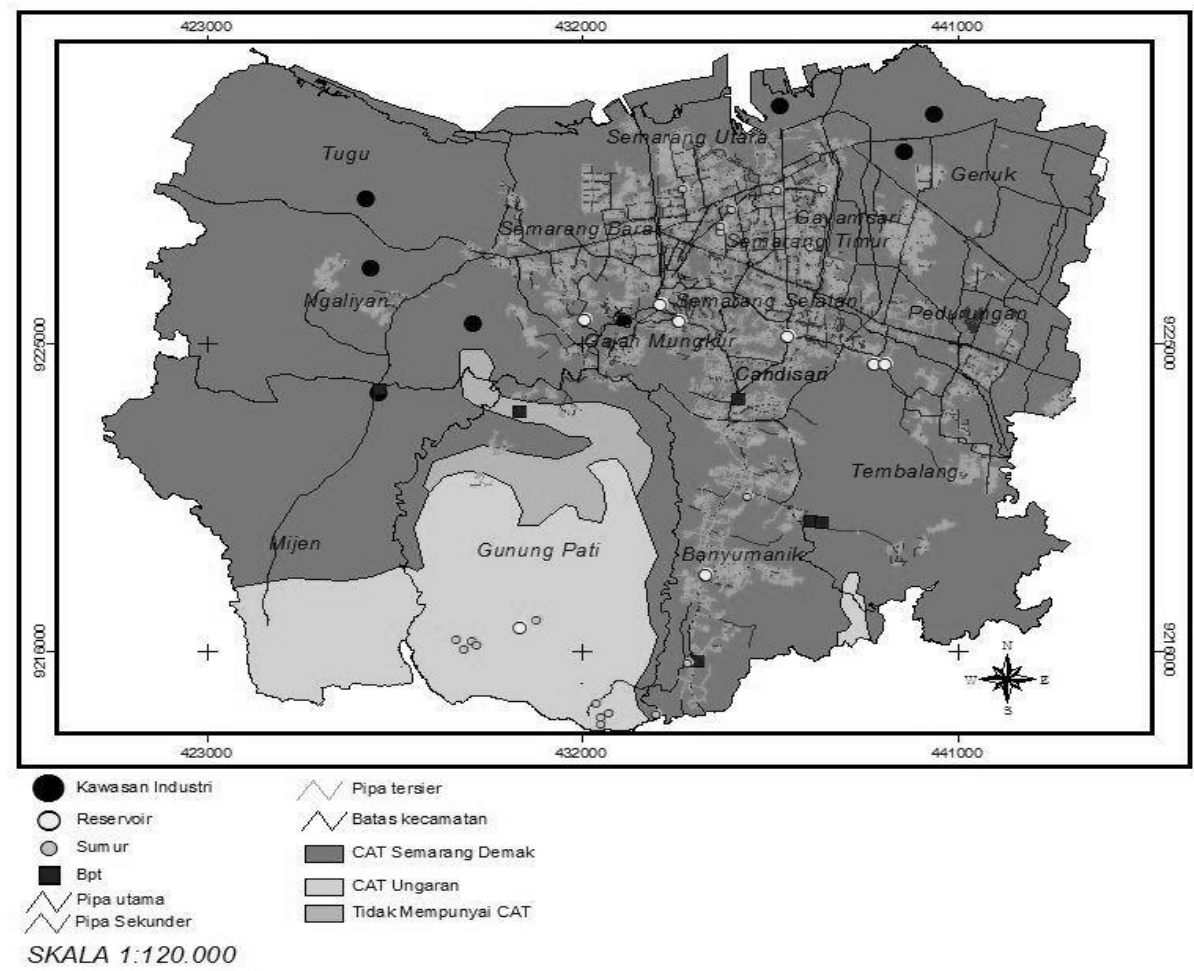

Sumber: Bappeda Kota Semarang, 2008.

\section{Gambar 3 Jaringan PDAM dan Lokasi Kawasan Industri}

Dari objek yang diteliti, dapat diidentifikasi bahwa sebanyak 3 (37.5\%) kawasan industri menyatakan kedalaman sumur bor artetis yang mereka operasikan tidak memerlukan izin dari dinas terkait. Sebanyak 5 ( $62.5 \%$ ) kawasan industri menyatakan sudah memiliki surat izin yang masih berlaku namun seluruhnya tidak dapat menunjukkan secara otentik surat izin tersebut. Bahkan tiga kawasan industri yang menyatakan sumur bor yang mereka operasikan tidak membutuhkan surat izin. Disamping itu, diketahui bahwa hanya 2 kawasan industri atau 25\% yang bersedia melampirkan surat izin sumur 
bor artetis, sedangkan 6 kawasan industri atau 75\% tidak dapat menunjukkan surat izin sumur bor. Dua kawasan industri yang bersedia menunjukkan surat izin pengeboran air tanah adalah di Kawasan Industri Tugu Wijayakusuma dan Kawasan Industri Terboyo. Situasi tersebut menjadi petunjuk bahwa sebagian besar kawasan industri (75\%) ditengarai melakukan ketidakpatuhan atau manipulasi perizinan yang tidak sesuai dengan persyaratan pengeboran sumur bor.

Pihak industri sebagai pemakai terbesar sumber air tanah memiliki kewajiban untuk melakukan upaya konservasi dan pendayagunaan air tanah. Diketahui bahwa hanya ada 2 ( $25 \%)$ kawasan industri yang menyediakan area atau sumur resapan, yaitu di Kawasan Industri Tugu Wijaya dan Kawasan Industri Terboyo; dan 1 kawasan industri (12,5\%) memiliki fasilitas Instalasi Pengolahan Air Limbah (IPAL) yaitu di Kawasan Industri Tugu Wijayakusuma; dan sebanyak $5(62.5 \%)$ kawasan industri tidak melakukan upaya konservasi dan pendayagunaan air tanah, dengan alasan belum ada Peraturan Daerah yang mengaturnya.

Dinas yang berhak melaksanakan pengawasan terhadap pemanfaatan air tanah di Kota Semarang adalah dinas PSDA Kota Semarang, bekerjasama dengan dinas ESDM Propinsi Jawa Tengah selaku penerbit rekomendasi teknis. PSDA masih kurang aktif dalam proses monitoring upaya konservasi dan pendayagunaan air tanah. PSDA hanya menunggu laporan penggunaan air tanah dari pihak industri dan jarang mengecek langsung ke lokasi kawasan industri. Kondisi tersebut menunjukkan kelemahan kontrol atau pengawasan terhadap upaya konservasi dan pendayagunaan air tanah. BLH selaku pengendali kerusakan lingkungan pun masih kurang maksimal kinerjanya. Karena jarang melakukan kunjungan pengawasan lapangan, maka gerakan upaya konservasi dan pendayagunaan air tanah tidak sampai kepada pihak industri. Sehingga penggunaan air tanah oleh pihak industri dilakukan secara sembarangan dan tidak mengikuti aturan.

Tabel 2. Pengawasan Oleh Dinas BLH dan PSDA Kota Semarang

\begin{tabular}{c|c|c|c|c|c}
\hline \multirow{2}{*}{ No } & \multirow{2}{*}{ Pengawasan } & \multicolumn{2}{|c|}{ BLH } & \multicolumn{2}{c}{ PSDA } \\
\cline { 3 - 6 } & & Jlh Kawasan & $\%$ & Jlh Kawasan & $\%$ \\
\hline 1 & Sekali tiap kuartal & 0 & 0.0 & 0 & 0.0 \\
\hline 2 & Sekali tiap semester & 1 & 12.5 & 0 & 0 \\
\hline 3 & Sekali setahun & 2 & 25 & 2 & 25 \\
\hline 4 & Jarang sekali & 2 & 25 & 1 & 12.5 \\
\hline 5 & Tidak pernah & 3 & 37.5 & 5 & 62.5 \\
\hline \multicolumn{2}{r|}{ Total } & 8 & 100 & 8 & 100 \\
\hline
\end{tabular}

Tabel 3. Data Potensi Pajak Air Tanah 2012

\begin{tabular}{l|l|l|l}
\hline No & $\begin{array}{c}\text { Klasifikasi } \\
\text { Pajak Air }\end{array}$ & $\begin{array}{c}\text { Wajib } \\
\text { Pajak }\end{array}$ & Nominal Pajak \\
\hline 1 & PDAM & 1 & Rp11.000.000 \\
\hline 2 & Industri Kecil & 24 & Rp292.000.000 \\
\hline 3 & Sosial Niaga & 21 & Rp62.000.000 \\
\hline 4 & Industri Besar & 16 & Rp154.000.000 \\
\hline 5 & Niaga Kecil & 250 & Rp1.300.000.000 \\
\hline 6 & Niaga Besar & 30 & Rp181.000.000 \\
\hline Total & & 270 & Rp2.000.000.000 \\
\hline
\end{tabular}

Sumber: DKPD Kota Semarang, 2012. 
Dinas Pengelolaan dan Keuangan Pajak Daerah (DPKD) selaku penarik pajak bagi wajib pajak pengguna air tanah berperan penting untuk menjaga peningkatan aktivitas pengambilan air tanah di Kota Semarang. Kepemilikan surat izin pengeboran dan pengambilan air tanah dapat diperoleh bilamana telah didahului oleh pembayaran pajak air tanah selama 3 bulan berturut-turut. Kepatuhan membayar pajak ini dapat dijadikan referensi dan rekomendasi penerbitan surat izin pengambilan air tanah (SIPA). Dibandingkan dengan hasil survei ke 8 kawasan industri Kota Semarang, terdata sebanyak 139 unit industri yang telah beroperasi, baik kecil maupun besar. Sedangkan total wajib pajak bagi industri kecil dan besar yang sudah terdaftar baru 40 unit industri. Artinya, baru sepertiga dari seluruh industri yang beroperasi yang terindikasi sudah memperoleh izin pengambilan air tanah.

\section{Kesimpulan}

Setelah mempertimbangkan beberapa temuan dari hasil penelitian ini selanjutnya disampaikan beberapa kesimpulan sebagai berikut :

a. Kawasan industri cenderung memilih menggunakan air tanah oleh karena PDAM tidak mampu memenuhi permintaan industri. Disamping itu, lokasi industri yang bertepatan di atas CAT menjadi pendorong bagi mereka untuk memanfaatkan potensi yang ada. Disamping biaya yang lebih murah, kontinuitasnya lebih terjamin.

b. Tingkat kepatuhan industri dalam mengurus surat izin sumur artesis dan upaya konservasi dan pendayagunaan air tanah dinilai relatif rendah.

c. Kurang terbukanya pengelola kawasan industri ataupun unit industri itu sendiri dalam memberikan data karakteristik pemanfaatan dan upaya konservasi air tanah dapat diakibatkan oleh tidak lengkapnya dokumen perizinan dan jumlah debit air tanah yang disadap melebihi ambang batasnya.

Berdasarkan tugas pemerintah dilihat pada Undang-Undang Sumber Daya Air dan Perda Air Tanah yang berlaku, maka mutu pengawasan terkait dengan pemanfaatan dan upaya konservasi dan pendayagunaan air tanah, dari Disperindag, ESDM, PSDA kota, BLH, dan DPKD Kota dinilai masih kurang.

\section{Daftar Pustaka}

Bappeda. 2010. Rencana Tata Ruang Wilayah Kota Semarang 2010 - 2030. Badan Perencanaan Pembangunan Daerah Kota Semarang.

ESDM Indonesia. 2000. Keputusan Menteri ESDM No. 1451 K/10/MEM/2000 tentang Pedoman Teknis Penyelenggaraan Tugas Pemerintah DiBidang Pengelolaan Air Bawah Tanah. Jakarta.

Kodoatie, Robert J dkk. 2002. Pengelolaan Sumberdaya Air Dalam Otonomi Daerah. Yogyakarta: Penerbit Andi.

Kodoatie, Robert J. 2003. Manajemen dan Rekayasa Infrastruktur. Yogyakarta: Pustaka Pelajar.

Nace, R.L. 1976. Hydrology, in Handbook of Water Resources and Pollution Control. New York: Van Nostrand Rinhold Company Inc.

Prihantoro, Feri. 2011. Ancaman Krisis Air Di Kota Semarang. www.bintari.org. Diakses tanggal 13 April 2011.

Republik Indonesia. 2004. Undang - undang No. 7 Tahun 2004 tentang Sumber Daya Air. Jakarta. 2008. Peraturan Pemerintah No. 42 tahun 2008 tentang Pengelolaan Sumber Daya Air. Jakarta. 2008. Peraturan Pemerintah No. 43 tahun 2008 tentang Air Tanah. Jakarta. 


\section{Kajian Pengawasan Pemanfaatan Sumberdaya Air Tanah di Kawasan Industri Kota Semarang}

Rizki, Lukman. 2003. Kajian Kebutuhan Air Bersih dan Identifikasi Ketersediaan Sumber Daya Air Bagi Pengembangan Kawasan Terpadu Gedebage. Tugas Akhir Departemen Teknik Planologi Institut Teknologi Bandung.

Singarimbun, M dan Soffian Effendi. 1995. Metode Penelitian Survei. Jakarta: Penerbit LP3ES. 